\title{
EN LA ESPERA
}

\section{Miguel MARTINÓN}

Para Andrés, y para Jordi, y para Pepita, unidos todos en el recuerdo de Marta, con quien compartimos el aire de aquellos días y el aura de aquellos tapices.

(La dame à la licorne, Musée de Cluny, París)

\begin{abstract}
Abre los lienzos de su pabellón
de damasco azul

secretamente alzado

entre pinos y acebos

robles y naranjos

y ahí se ve a sí misma

eligiendo del cofre

que la doncella sostiene

las ricas joyas con que se engalana

y jubilosa se dispone

para la espera

y abstraída en su dicha sale

pasea solitaria

por la isla de su jardín

sintiendo que en el aire

unánime ya todo alienta

sólo para su deseo
\end{abstract}

En la espera

sale sola al jardín

el terciopelo azul de su vestido

lánguidamente se desliza

sobre las hierbas

atraída por el azahar 
camina hacia el naranjo

absorta mira más allá

de las flores y los frutos

se ve a sí misma

flotando en el aroma

que impregna el armiño

y los cabellos juveniles

abrazados con la diadema

palpando cuidadosa

el tronco absorto del acebo

el asta enhiesta del unicornio

En la espera

recorre taciturna

las sombras temblorosas del jardín

sale deslumbrada a la luz

se detiene en la rosaleda

se ve a sí misma

en la paz de la duermevela

cogiendo de la copa

que ya le tiende la doncella

la golosina para el pájaro

que ha llegado hasta su mano

y mecánico repite

el fiel anuncio del encuentro

En la espera

se adentra ensimismada

en el ámbito sigiloso

de aquella magia del jardín

se olvida de las rosas

se ve a sí misma

mecida en el ensueño de la hora

tocada con la corta cofia

eligiendo de la bandeja

que ya le ofrece la doncella

los claveles que va ensartando

para tejer jovial 
esa hermosa corona

con colores y olores

de joven desposada

En la espera

va hacia la glorieta

de los acebos y naranjos

absorta llega

hasta aquel cenador oculto

en que la música del órgano

siempre aguarda callada

y ella se ve a sí misma

erguida en la penumbra incierta

con las trenzas

entrelazadas y adornadas

sobre la frente

allí de pie serena

auxiliada por la doncella

moviendo sabiamente sus dedos

sobre las teclas que el amor conoce

diciendo siempre muda

unas palabras que el amor

le va inspirando ardientes

En la espera

deambula por la arboleda

sin rumbo cierto

acarrea su largo silencio

encuentra ya un descanso

a la sombra del roble

y ahí se ve a sí misma

solitaria sentada

en la amable espesura

se ha mirado en el espejo

fatigada por la inquietud

y ahora mira y amorosa abraza

al más tierno unicornio

que complacido se contempla 
en el espejo

por la más dulce mano sustentado

Tras el descanso

se recoge en su pabellón

de damasco azul

secretamente alzado

entre pinos y acebos

robles y naranjos

y ahí se ve a sí misma

guardando en el cofre

que la doncella sostiene

las ricas joyas de que se desprende

en el final ya de la espera

sintiendo que en el aire

todo gira y se eleva unánime

en la hora sin hora

e inquieta y jubilosa va a entregarse

a su solo deseo

Del libro inédito Estación sucesiva 